\title{
The Effect Variation Arch of Rotor Blade On The Performance Of Kinetic Turbine
}

\author{
Bernadus S. Wuwur ${ }^{1}$, Dedy Nataniel Ully ${ }^{1}$, Paula Rita ${ }^{1}$ \\ \{benwuwur70@gmail.com, dedy.ully@gmail.com, paularita@gmail.com\} \\ Politeknik Negeri Kupang ${ }^{1}$
}

\begin{abstract}
Energy needs in Indonesia are currently still dominated by fossil fuel-based energy, such as petroleum and coal. Therefore, it is necessary to develop alternative energy sources that can replace fossil energy sources with renewable energy such as water energy as electricity generation. The purpose of this study is to determine the effect of rotor blade curvature variations on the performance of kinetic turbines. The kinetic turbine used has three variations of rotor blade curvature which are 40,50 and $60 \mathrm{~mm}$ with four variations of water flow velocity namely $1.52,2.5,3,3.5 \mathrm{~m} / \mathrm{s}$. This research was conducted with real experimental methods at a laboratory scale. The results showed that there was an increase in performance when there were variations in rotor blade curvature. The $60 \mathrm{~mm}$ rotor blade curvature has the highest efficiency value of $23.73 \%$ then the $50 \mathrm{~mm}$ rotor blade curvature has an efficiency value of $18.88 \%$ and the lowest efficiency value occurs at the $40 \mathrm{~mm}$ rotor blade curvature.
\end{abstract}

Keywords : Kinetic Turbine, Arch, Rotor blade, Performance, Water Energy

\section{Introduction}

Energy needs in Indonesia are currently still dominated by fossil fuel-based energy, such as petroleum and coal. The disadvantage of fossil fuels is that they are not environmentally friendly, because the results of burning fossil fuels in the form of carbon dioxide gas, carbon monoxide, hydro carbon, sulfur oxides, nitrous oxide and other poisonous gases are very dangerous to human health. For this reason, it is necessary to develop alternative energy sources that can replace fossil-based energy sources with renewable energy such as water, wind, solar, geothermal, biodiesel, bioethanol, biomass and other energy. The most potential renewable energy source in Indonesia is the utilization of water energy as electricity generation and if the utilization is carried out thoroughly, then our chances to get out of the electricity crisis will be greater, because there are many places that have the potential to be utilized and spread throughout the islands. in Indonesia. Utilization of water energy is usually by using an energy conversion tool that is a water wheel. The kinetic energy of water is captured by blades with a certain area, so that it produces rotational motion to rotate the turbine rotor. Turbine rotor rotation is able to rotate the generator shaft so that it will produce electrical energy [1].

East Nusa Tenggara, especially Sabu Raijua Regency has mountainous and hilly topographical conditions, so that it is drained by many rivers and in some areas there are dams so that it is suitable for use as a hydroelectric power station. One option in utilizing the potential of water energy in dams is the speed of water flow that has kinetic energy. For this reason, in this research a kinetic turbine with a bowl shaped blade is needed to hold the flow in order to increase the tangential force produced. One of the areas in Sabu Raijua Regency that has water energy potential is the Muli hamlet, where the source of water is located in hilly areas that are dammed and channelled through irrigation channels to paddy fields, making it possible to create power plants at micro scale. 
The development of kinetic turbines as micro scale power plants has been done by several previous researchers such as research on the effect of variations in the number of blades on optimizing the performance of a single wheel kinetic turbine. The results showed that the number of blades affected the performance of the kinetic turbine where the flow of water 0.013 round $100 \mathrm{rpm}$, the number of blades 5 had a power of 5.50, blades 7 had power as much as having a higher performance than the number of blades 5, 7, and 9, especially at round $100 \mathrm{rpm}$ the power produced is $20.41 \mathrm{Watt}$ [2].

Further development and research are also carried out namely on the effect of variations in blade shape on the performance of kinetic water turbines. The results showed that the influence of the blade shape on the performance or power and efficiency of the kinetic water turbine that is the shape of the blade has the power and efficiency higher than the shape of the blade and flat blade. Maximum turbine power and efficiency occur at the arc blade with values of 4.699 Watt and $29.659 \%$, then decrease at the bowl blade with power and efficiency values of 4.508 Watt and $28.457 \%$. While the lowest turbine power and efficiency occur flat blade with power and efficiency values of 3.080 Watt and $19.439 \%$ [3].

Further research and development is carried out on vertical shaft type water flow turbines with the Computation Fluid Dynamic (CFD) simulation process and experimentally. The purpose of this study is to obtain the force fluctuations caused by changes in blade number and turbine aspect ratio and to analyze the ripple torque effect that occurs. The results obtained based on experimental analysis is that adding the number of blades will increase the rpm of the turbine. Meanwhile, from the simulation results, the force fluctuations produced by turbines with fewer blades have lower fluctuations. The best turbine efficiency produced by the turbine is $54.6 \%$ [4].

Further research and development is carried out on vertical shaft cross-flow water turbines using helical blades. The main objective of this research is to demonstrate the ability of a water turbine with helical blade to extract useful power from a water stream. From the experimental studies on the prototype obtained a turbine efficiency of $17 \%$ and the maximum power produced was 17.98 watts at a flow speed of $1.2 \mathrm{~m} / \mathrm{s}$ [5].

Further research and development is carried out in the manufacture of prototype kinetic turbine (double runner) This research is also based on the theory of the triangle speed, the dual wheel kinetic turbine that adopts a pocelet water wheel and will receive special attention, especially the turbine blade angle, the angle of arrival of the turbine wheel water flow and the number of blades that will get a collision velocity (kinetic) flow water enters the turbine. The research method used is an experimental method by varying the angle of the turbine blade, the angle of arrival of the flow of water in the turbine wheel and the number of blades that will get a collision of water so that the optimal turbine design is obtained. From the results of the initial research it was found that the prototype kinetic turbine produced a maximum power of 134 Watt at a discharge of 1 liter per second and a flow speed of $2 \mathrm{~m} / \mathrm{sec}$ [6].

Further research and development is carried out on vertical axis kinetic turbines with the power produced by $5 \mathrm{~kW}$ which is stable, peaking with rotor efficiency of more than $35 \%$ and producing electricity consistently. This technology is proven to be versatile both in summer and winter. The advantage of a vertical axis turbine is its ability to avoid impacts and minimize significant damage to the rotor and be able to maintain power output at various seasons, thus demonstrating durability and reliability. Hydrofoil support is the best because it contributes the least to rotor dynamics. With the support of the arm the turbine is able to operate on currents at a speed of $2 \mathrm{~m} / \mathrm{s}$, which contradicts some of the literature listed on the Darrieus turbine which cannot start when the grid is connected. During the winter in 2008, all research equipment was wrapped in ice along with a turbine for a week. This situation proves that it will be dangerous for the equipment so that the ice is cleaned regularly. This technology would not be feasible to operate if there was no maintenance throughout the winter. Good structural support units designed to freeze placing turbines in submerged positions if design considerations are made to reduce turbine performance problems. If placed on the surface, the kinetic turbine unit with vertical shaft still needs protection to keep it installed throughout the year [7]. 


\section{Experimental and Procedure}

This study uses a real experimental method on a laboratory scale that is testing a treatment of directing mounting and rotor blade curvature variations on the performance of kinetic turbines, at various variations in water flow velocity and then comparing it to obtain an interconnected event pattern. Thus, it can be seen the magnitude of the curvature of the rotor blade at a particular water flow velocity which results in maximum performance. The prototype of the kinetic turbine is placed between the water pump and the flow controller so that it is easily exposed to water, then the kinetic turbine will rotate when there is a certain amount of water that hits the turbine blade with a certain flow speed. Data retrieval starts when the kinetic turbine is spinning stable and can turn on several LED lights. Each retrieval of research variables was repeated five times to get an average value. The data to be taken are the rotor rotation (rpm), the voltage of the electric generator (Volt) and the strong electric current (Ampere). Research instrumentation can be seen in Figure 1.

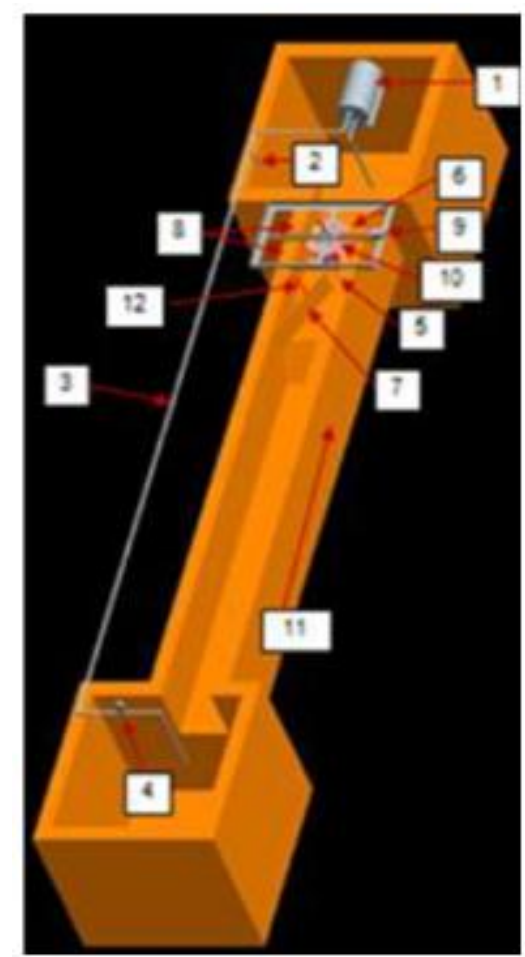

Caption:

1. Water pump

2. Discharge valve;

3. Main water supply pipes;

4. Flowmeter:

5. Flow wactmeter

6. Kinetic turbine;

7. Steering flow;

8. Spring Balance;

9. Tachometer;

10. Pulley

11. Flow direction;

12. The direction or slope of the flow guide.

Figure 1. Chart of research using kinetic turbines

\subsection{Equations, formulas and code}

\section{a. Kinetic Turbine of Power}

Kinetic turbine only utilizes water flow or river current velocity (irrigation channel), the available water energy is kinetic energy as in equation 1 namely:

$$
E_{a}=\frac{1}{2} \cdot \dot{m} \cdot v^{2}
$$


Where :

$$
m=\rho \cdot Q, Q=v \cdot A
$$

Where :

$$
\begin{aligned}
& m=\text { Mass water flow rate }(\mathrm{kg} / \mathrm{s}) \\
& \rho=\text { density of water }\left(\mathrm{kg} / \mathrm{m}^{3}\right) . \\
& \text { A }=\text { Extent of channel guideing the turbine blade }\left(\mathrm{m}^{2}\right) . \\
& v=\text { Velocity of flow }(\mathrm{m} / \mathrm{s}) . \\
& \mathrm{Q}=\text { Water discharge }\left(\mathrm{m}^{3} / \mathrm{s}\right)
\end{aligned}
$$

\section{b. Power of water}

While the water power flowing at a certain cross section for the calculation is used the equation below:

Where is $\mathrm{Ea}=\mathrm{Pa}$

$m=\rho . v$.

$\mathrm{Pa}=1 / 2 \cdot \rho \cdot \mathrm{A} \cdot v^{3}$

Where :

$\mathrm{P}_{\mathrm{a}}=$ Power of water (Watt).

$\rho=$ Density of water $\left(\mathrm{kg} / \mathrm{m}^{3}\right)$.

$\mathrm{A}=$ Extent of the direction of the channel drains the turbine blade $(\mathrm{m} 2)$.

$v=$ Velocity of flow $(\mathrm{m} / \mathrm{s})$.

\section{c. Power of Turbine}

To calculate the amount of turbine power generated due to the presence of kinetic energy, equation 4 is used below:

$\mathrm{P}_{\mathrm{t}}=T . \omega$

So that :

$T=F_{t} . R$

$\omega=\frac{2 . \pi \cdot n}{60}$

Where :

$\mathrm{P}_{\mathrm{t}}=$ Power of turbine (Watt).

$\mathrm{F}_{\mathrm{f}}=$ Force of Tangential $(\mathrm{N})$.

$\mathrm{R}=$ Pully radius $(\mathrm{m})$.

$\mathrm{T}=$ Torque $(\mathrm{Nm})$.

$\omega=$ Angular velocity (Radians/sec).

$\mathrm{n}=$ Turbine shaft or wheel rotation $(\mathrm{rpm})$.

d. Efficiency of kinetic turbine

The efficiency of kinetic turbine is determined by the ratio between the incoming water energy and the amount of energy produced by the kinetic turbine as in equation 7 below:

$\eta=\frac{P_{t}}{P_{a}} \times 100 \%$ 
Where :

$\eta=$ efficiency $(\%)$

$\mathrm{P}_{\mathrm{t}}=$ Power of turbine $($ Watt $)$

$\mathrm{P}_{\mathrm{a}}=$ Power of water (Watt)

\section{Results and Discussion}

\subsection{Results}

Table 1. Data processing results in the form of water power, torque, turbine power and efficiency at the curvature of the rotor blade $40 \mathrm{~mm}$ at various variations in flow speed.

\begin{tabular}{|c|c|c|c|c|c|c|}
\hline No & Variable & $1,5 \mathrm{~m} / \mathrm{s}$ & $2 \mathrm{~m} / \mathrm{s}$ & $2,5 \mathrm{~m} / \mathrm{s}$ & $3 \mathrm{~m} / \mathrm{s}$ & $3,5 \mathrm{~m} / \mathrm{s}$ \\
\hline 1. & Rotation (rpm) & 15,33 & 28,66 & 41,66 & 67,66 & 85 \\
\hline 2. & Torque (N. m) & 1,17 & 2,74 & 4,12 & 5 & 6,76 \\
\hline 3. & $\begin{array}{l}\text { Power of water } \\
\text { (Watt) }\end{array}$ & 37,9 & 89,83 & 173,45 & 303,20 & 481,44 \\
\hline 4. & $\begin{array}{l}\text { Power of turbine } \\
\text { (W) }\end{array}$ & 1,87 & 8,23 & 17,96 & 35,42 & 60,17 \\
\hline 5. & Efficiency (\%) & 4,95 & 9,17 & 10,35 & 11,68 & 12,49 \\
\hline
\end{tabular}

Table 2. Data processing results in the form of water power, torque, turbine power and efficiency at $50 \mathrm{~mm}$ rotor blade curvature at various variations in flow speed.

\begin{tabular}{|c|c|c|c|c|c|c|}
\hline No & Variable & $1,5 \mathrm{~m} / \mathrm{s}$ & $2 \mathrm{~m} / \mathrm{s}$ & $2,5 \mathrm{~m} / \mathrm{s}$ & $3 \mathrm{~m} / \mathrm{s}$ & $3,5 \mathrm{~m} / \mathrm{s}$ \\
\hline 1. & Rotation (rpm) & 22,33 & 36,33 & 52,33 & 78,33 & 96 \\
\hline 2. & Torque (N. m) & 1,37 & 3,43 & 5,19 & 6,47 & 9,02 \\
\hline 3. & $\begin{array}{l}\text { Power of water } \\
\text { (W) }\end{array}$ & 37,9 & 89,83 & 173,45 & 303,20 & 481,44 \\
\hline 4. & $\begin{array}{l}\text { Power turbine } \\
\text { (W) }\end{array}$ & 3,19 & 13,05 & 28,47 & 53,07 & 90,68 \\
\hline 5. & Efficiency $(\%)$ & 8,42 & 14,53 & 16,39 & 17,5 & 18,88 \\
\hline
\end{tabular}

Table 3. Data processing results in the form of water power, torque, turbine power and efficiency at $60 \mathrm{~mm}$ rotor blade curvature at various variations in flow speed.

\begin{tabular}{|c|c|c|c|c|c|c|}
\hline No & Variable & $1,5 \mathrm{~m} / \mathrm{s}$ & $2 \mathrm{~m} / \mathrm{s}$ & $2,5 \mathrm{~m} / \mathrm{s}$ & $3 \mathrm{~m} / \mathrm{s}$ & $3,5 \mathrm{~m} / \mathrm{s}$ \\
\hline 1. & Rotation (rpm) & 23,33 & 45,33 & 61,66 & 85,66 & 107 \\
\hline 2. & Torque (N. m) & 1,56 & 3,82 & 5,78 & 7,25 & 10,2 \\
\hline 3. & $\begin{array}{l}\text { Power of water } \\
\text { (W) }\end{array}$ & 37,9 & 89,83 & 173,45 & 303,20 & 481,44 \\
\hline 4. & $\begin{array}{l}\text { Power turbine } \\
\text { (W) }\end{array}$ & 4,65 & 18,13 & 37,35 & 65,08 & 114,26 \\
\hline 5. & Efficiency (\%) & 12,26 & 20,18 & 21,53 & 21,46 & 23,73 \\
\hline
\end{tabular}

\subsection{Discussion}

Results and discussion can be displayed in graphical form so that based on trends in the graph, causal relationships will be seen and some conclusions. 


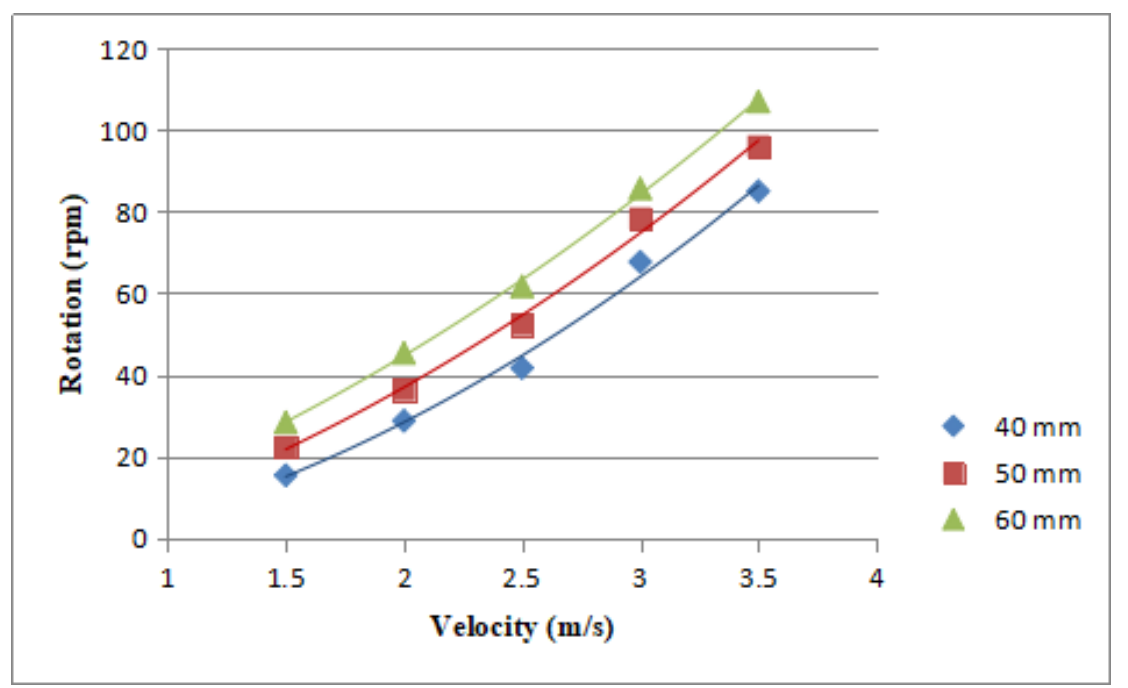

Figure 2. Relationship between flow velocity Vs of rotation produced by the turbine

Based on the graph above shows that the rotation (rpm) will increase linearly with the addition of flow velocity $(\mathrm{m} / \mathrm{s}$ ) in the three variations of rotor blade curvature. The magnitude of the increase in rotation value is determined by the amount of water temperature $(\mathrm{kg})$ and water discharge (m $3 / \mathrm{s}$ ) received by the rotor blade. The rotor blade that has the greatest curvature of $60 \mathrm{~mm}$ has the highest rotation value of $107 \mathrm{rpm}$, followed by the rotor blade with curvature of $50 \mathrm{~mm}$ and $40 \mathrm{~mm}$ which is $96 \mathrm{rpm} 85 \mathrm{rpm}$ and all of them occur at a maximum flow speed of $3.5 \mathrm{~m} / \mathrm{s}$. The rotation value is also determined by the angular velocity (radians / $\mathrm{sec}$ ) and torque (Newton. Meters) produced by a water turbine.

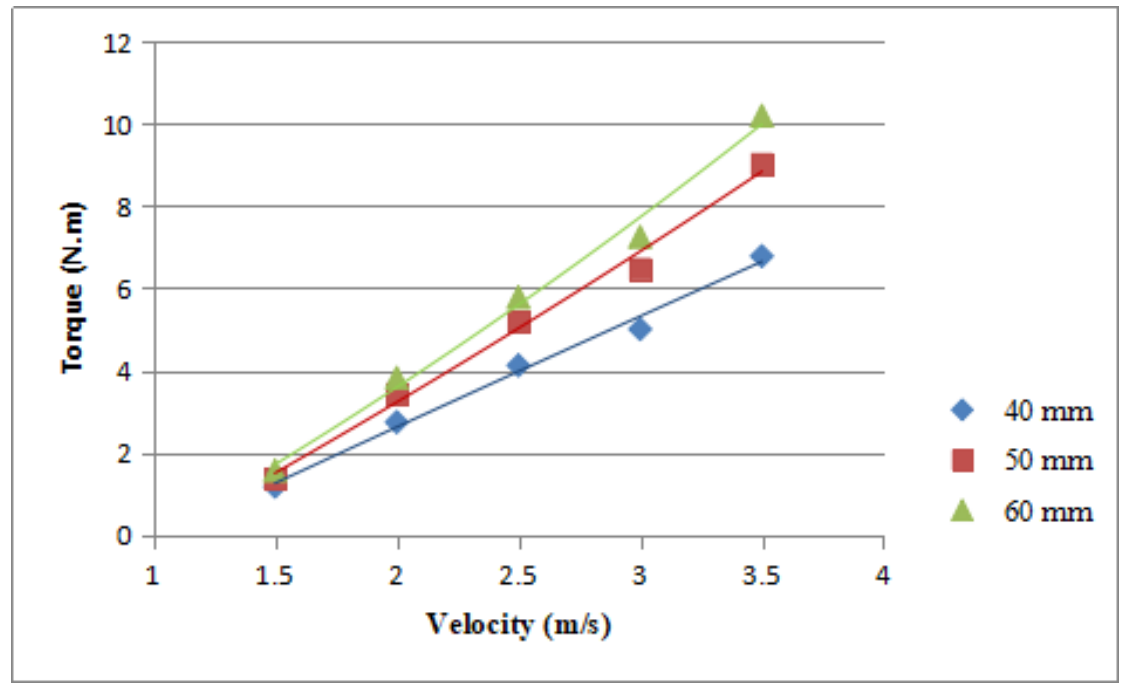

Figure 3. Relationship between flow velocity Vs of torque 
Based on the graph above shows that the torque value (N.m) increases linearly with the addition of flow velocity $(\mathrm{m} / \mathrm{s})$ given to the three variations of rotor blade curvature. The amount of increase in torque value is largely determined by the amount of load received by the turbine rotor and also the amount of mass of water received by the turbine rotor blade. The greater the curvature of the rotor blade, the greater the torque value generated. The greatest curvature of the rotor blade, $60 \mathrm{~mm}$, has the highest torque value of $10.2 \mathrm{~N}$. m, followed by the curvature of the rotor blade $40 \mathrm{~mm}$ and $50 \mathrm{~mm}, 6.76 \mathrm{~N} . \mathrm{m}$ and $9.02 \mathrm{~N}$. m and all occur at a maximum flow velocity of $3.5 \mathrm{~m} / \mathrm{s}$.

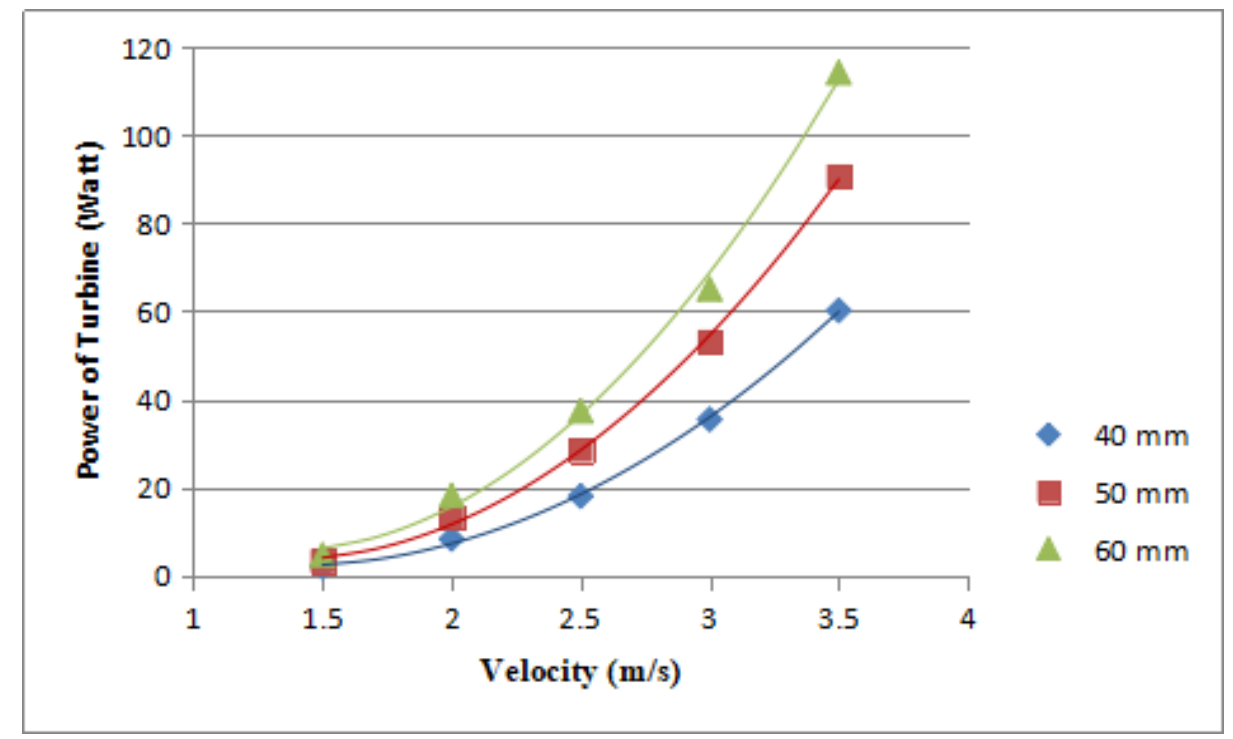

Figure 4. Relationship between flow velocity Vs Turbine Power

Based on the graph above it can be seen that the turbine power is significantly increased in various variations of the rotor blade curvature with the addition of a given flow velocity. The amount of increase in the value of the turbine power is determined by the torque, angular speed, rotation value and the amount of rotor blade curvature produced by the turbine rotor. The greatest curvature of the rotor blade, $60 \mathrm{~mm}$, produces the greatest turbine power, 114.26 Watt, followed by a curvature of $40 \mathrm{~mm}$ and $50 \mathrm{~mm}, 60.17$ Watt and 90.68 Watt. The highest turbine power occurs at a flow speed of $3.5 \mathrm{~m} / \mathrm{s}$ which is the highest speed. 


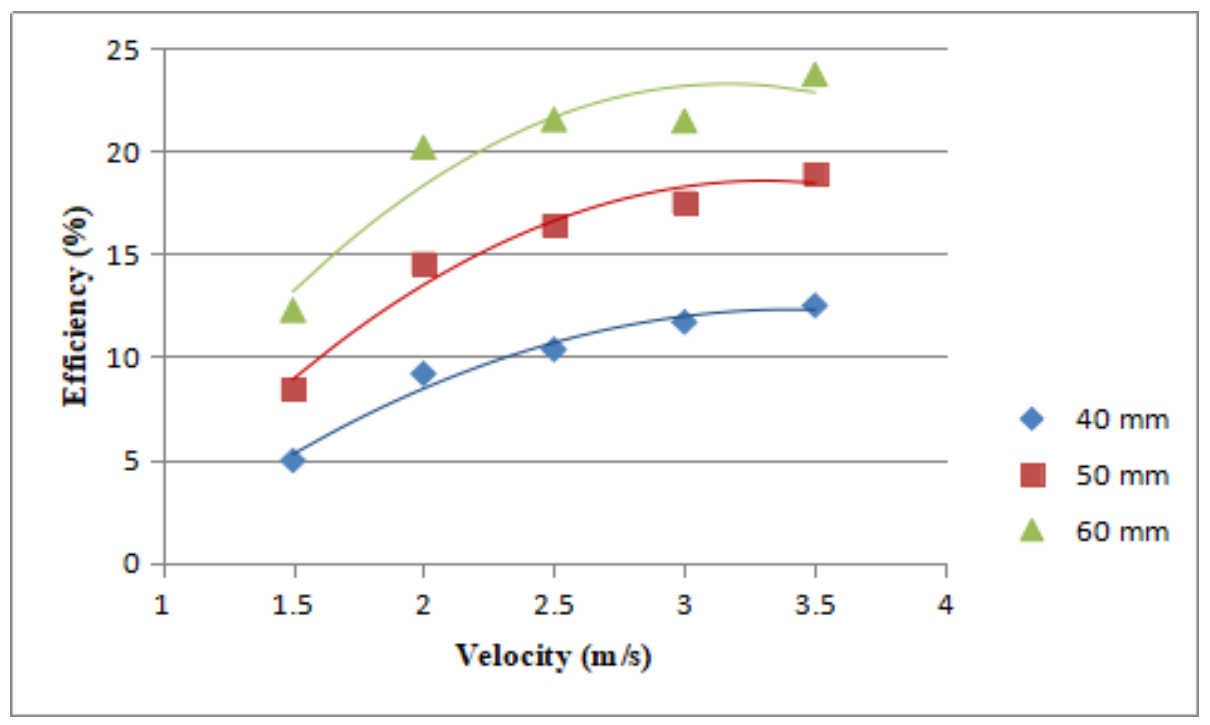

Figure 5. Relationship between flow velocity Vs efficiency

Based on the graph above it can be seen that the efficiency increases parabolically along with the addition of the value of the given flow velocity. The amount of efficiency is greatly influenced by the rotation value, angular velocity, torque and power produced by the turbine. The rotor blade curvature $60 \mathrm{~mm}$ has the highest efficiency value of $23.73 \%$ at a flow velocity of $3.5 \mathrm{~m} / \mathrm{s}$, followed by a $50 \mathrm{~mm}$ blade curvature of $18.88 \%$ and the lowest efficiency occurs at a $40 \mathrm{~mm}$ curvature of $12.49 \%$.

\section{Conclusion}

From the results of the discussion above, it can be concluded that:

1. Improved kinetic turbine performance is different in each variation of rotor blade curvature and flow velocity variations.

2. Rotor blade curvature $60 \mathrm{~mm}$ has the highest efficiency value of $23.73 \%$ then $50 \mathrm{~mm}$ rotor blade curvature has an efficiency value of $18.88 \%$ and the lowest efficiency value occurs in the $40 \mathrm{~mm}$ rotor blade curvature.

\section{References}

[1]. Arismunandar; W. 2004. Penggerak Mula Turbin, Edisi Ketiga ITB, Bandung.

[2]. Ariadi; H. Nugroho; R. 2011. Studi Numerik dan Eksperimental performansi Turbin Arus Air Tipe Vertikal Aksis Dengan Variasi Jumlah Blade dan efek Aspect Ratio, Teknik Fisika Fakultas Teknologi Industry, ITS-Undergraduate-16411-paper-pdf.

[3]. Eric; B. Shamez, K. John, W. Tom; M. Clayton; Bear. 2009. Operating A 5-kW GridConnected Hydrokinetic Turbine Ariven In Cold Climates.

[4]. Pietesrz; R. 2013. Pengaruh Jumlah Sudu Terhadap Optimalisasi Kinerja Turbin Kinetik Roda Tunggal. Jurnal Rekayasa Mesin Vol.4, No.3 Tahun 2013: 220-226. ISSN 0216468X. 
[5]. Soenoko; R. 2010 Optimasi Unjuk Kerja Turbin Kinetik Roda Ganda Sebagai Pembangkit Listrik Pedesaan,.Laporan hibah penelitian strategis nasional tahun anggaran 2010.

[6]. Santoso; D. Yanto dan Marwani, 2011. Studi Eksperimental Pada Turbin Air Aliran Lintang Yang Menggunakan Sudu Helical Dengan Penampang Airfoil. Prosiding Seminar Nasional AVoER ke-3 Palembang, 26-27 oktober 2011. ISBN : 979-587-395-4.

7. Yani. A; Mihdar; Erianto. R; 2016. Pengaruh Variasi Bentuk Sudu Terhadap Kinerja Turbin Air Kinetik. Jurnal TURBO Vol. 5 No. 1. 2016. p-ISSN: 2301-6663, e-ISSN: 2477-250X. 